\title{
Preparation of Polycrystalline Silicon from Rice Husk by Thermal Decomposition and Aluminothermic Reduction
}

\author{
Ahmad Nuruddin ${ }^{1,2 *}$, Brian Yuliarto ${ }^{1,3}$, Adhitya Gandaryus Saputro ${ }^{1,3}$, Badruzaman $^{2}$ and Aditianto Ramelan ${ }^{2}$ \\ ' Advanced Functionals Materials Laboratory, Engineering Physics Department, Faculty of Industrial \\ Technology, Institut Teknologi Bandung, Jalan Ganesha 10 Bandung 40132, Indonesia \\ ${ }^{2}$ Materials Engineering Study Program, Faculty of Mechanical and Aerospace Engineering, Institut Teknologi \\ Bandung, Jalan Ganesha 10 Bandung 40132, Indonesia \\ ${ }^{3}$ Research Center for Nanosciences and Nanotechnology, Institut Teknologi Bandung, Jalan Ganesha 10 \\ Bandung 40132, Indonesia
}

*Corresponding author email: nuruddin@tf.itb.ac.id

Received August 23, 2019; Accepted February 03, 2020; Available online March 15, 2020

\begin{abstract}
Polycrystalline silicon was extracted from rice husk by thermal decomposition and aluminothermic methods. Rice husk was thermally decomposed under various heat treatments and acid purifications. High purity silica of $99.81 \%$ was obtained by subsequent rice husk washing, pressure cooking in mixed chloride acid peroxide solution, and burning at $500^{\circ} \mathrm{C}$ for one hour. Aluminothermic reduction of silica was conducted at various calcination temperatures. It is found that $78.6 \%$ of silica was converted to silicon for calcination temperature of $800^{\circ} \mathrm{C}$. Leaching the reduction product with strong hydrochloric and hydrofluoric acids produced silicon polycrystalline with a purity of $99.91 \%$.
\end{abstract}

Keywords: polycrystalline silicon, rice husk ash, aluminothermic reduction

\section{INTRODUCTION}

At present, Indonesia is the third-largest producer of paddy rice in the world, sharing about 74.2 million metric tonnes or $9.78 \%$ of world total rice production in 2017 (FAO, 2017). Assuming that its rice husk contains about 20\% silica (Kumar, Ramakrishnan, Kirupha, \& Sivanesan, 2010; Fijalkowski et al., 2016), then Indonesia has a significant potential annual production of about 2 million tons of silica, and possibly silicon powder with further processing for various technological applications.

High purity silica powder can be extracted from rice husk by various routes of heat and chemical treatments. Alkali-acid precipitation method was the most common for extracting silica from rice husk ash. Sodium hydroxide or potassium hydroxide was frequently chosen to dissolve silica into a sodium silicate solution. There were options in using acid to precipitate silica. Among available strong acids, chloride acid was a preference solution used (Azat et al., 2019). However, there were growing interests that acid pre-treatment rice husk ash could enhance silica yield and reduce the impurity (Selvakumar et al., 2014). There were also attempts to use hydrothermal and pressurized hot water or acid solution to pre-treat rice husk prior to the incineration step and resulted in silica with similar purity to the silica processed with alkali-acid precipitation (Ugheoke \& Mamat, 2012).
However, the later methods have not been commonly used and explored.

Silica can be reacted with a reduction agent under certain temperature to form silicon. Several chemical elements or metals, such as carbon, calcium, magnesium, and aluminum, are preferably used as the reduction agent. Loutzenhiser, Tuerk, \& Steinfeld (2010) performed silica reduction by a carbothermal method in concentrated solar energy. Vacuum and high-temperature reactions are required for this reduction process. However, this method only yielded relatively low silicon purity of $66-79 \%$. Calcium is thermodynamically the most reactive element for calciothermic process. The exothermic nature of calcium-silica reaction, which has potential explosion, made it impractical for calciothermic process (Houli ef al., 2018). Recently, Ali, El-Sadek, Morsi, El-Barawy, \& Abou-Shahba (2018) reported the carbothermic reduction process of Egyptian quartz using the high power of electrical furnace to recover about $75 \%$ polysilicon with about $97 \%$ purity. Several researchers carried out a magnesiothermic reduction of silica at a temperature between $600-950^{\circ} \mathrm{C}$. A maximum Si yield more than $99.9 \%$ was achieved (Barati, Sarder, McLean, \& Roy, 2011; Won, Nersisyan, \& Won, 2011; Larbi, Barati, \& McLean, 2013; Swatsitang \& Krochai, 2009; Houli et al., 2018). Barati, et al, (2011) and Larbi, et al, (2013) reduced silica from rice husk and 
silica fume, respectively, by magnesium excess to produce maximum yield $\mathrm{Si}$ in the final reduction product. A lower price of aluminum over magnesium has attracted many researchers to use it for aluminothermic processes of silica. Okutani (2017) performed an aluminothermic reduction of silica at relatively high temperatures $\left(1000-1300^{\circ} \mathrm{C}\right)$. They found about $70 \%$ weight of silica can be reduced to form silicon. However, the reduction of silica at elevated temperature means higher costs for the production of silicon. According to the Ellingham diagram, aluminum should thermodynamically be feasibly reduced silica to silicon at a temperature as low as $650^{\circ} \mathrm{C}$, with free Gibbs energy of $-180 \mathrm{~kJ}$ (Lynch, 2009).

In this paper, we report the preparation of polycrystalline silicon from rice husk through thermal decomposition of husk to produce silica powder, and the aluminothermic reduction process of silica powder by using 5 wt.\% excess of aluminum at moderate temperatures and leaching the reduction product in strong chloric and fluoric acid. The effect of various calcination temperature and leaching during aluminothermic reduction was investigated.

\section{EXPERIMENTAL SECTION}

Rice husk used in this experiment was obtained from South Bandung, West Java, Indonesia. Acetic acid $\left(\mathrm{CH}_{3} \mathrm{COOH}\right)$, ethylene glycol $\left(\mathrm{C}_{2} \mathrm{H}_{6} \mathrm{O}_{2}\right)$, hydrogen peroxide $\left(\mathrm{H}_{2} \mathrm{O}_{2}\right)$, chloric acid $(\mathrm{HCl})$, and potassium hydroxide $(\mathrm{KOH})$ were obtained from Merck without further purification. Stainless steel pressurized cooker $80 \mathrm{kPa}$ was utilized for roasting the rice husk, and a temperature regulated of the electric furnace was used to burn out the dried husk. Prior chemical and heat treatment, $100 \mathrm{~g}$ rice husks were rinsed in water to remove dirt. Eight samples were treated differently, as shown in Table 1.

Sample 1 was a raw rice husk without treatments. Sample 2 only underwent heat treatment, whilst sample 3 was roasted in plain water prior to heat treatment. Samples 4 to 7 underwent roasting in a pressure cooker with 5 vol.\% acetic acid solution, 5 vol.\% acetic acid and 70 vol.\% ethylene glycol solution, 5 vol. $\%$ acetic acid and 50 vol.\% hydrogen peroxide solution, 50 vol. $\%$ hydrogen peroxide and 5 vol. \% chloride acid solution, respectively. Samples 2 to 7 were heat-treated at $500^{\circ} \mathrm{C}$ for one hour in an electric furnace to burn out carboxyl elements. White silica powder was then obtained. For comparison, the extraction of silica in sample 8 was performed using the alkali fusion method (Yuvakkumar, Elango, Rajendran, \& Kannan, 2014). The rice husk in sample 8 was burnt out to form white ash, which was reacted with $50 \mathrm{ml}$ of $1 \mathrm{M} \mathrm{KOH}$ under constant stirring to produce potassium silicate. The potassium silicate solution was filtered to remove the ash residue. The filtered sodium silicate solution was titrated with $1 \mathrm{M}$ $\mathrm{HCl}$ under constant stirring. The titration was stopped when the $\mathrm{pH}$ of the solution has reached 7 to produce silica gels. After aging for $24 \mathrm{~h}$, the gel was diluted in $100 \mathrm{ml}$ of distilled water to make a slurry, which subsequently washed two times with distilled water. White silica powder was obtained after drying the washed slurry in hot air with constant convection flow for $10 \mathrm{~h}$. The major component of raw husk in sample 1 and silica powder obtained in samples 2 through 8 were quantified by X-ray fluoroscopy (XRF, EDAX ORBIS AMETEK) in combination with chemical gravimetric analysis. The sample containing the highest percentage of silica was used as a starting material for aluminothermic reduction.

Prior to aluminothermic reduction, silica powder was leached with $1.0 \mathrm{M} \mathrm{HCl}$ at $70^{\circ} \mathrm{C}$ and dried in the oven at $100^{\circ} \mathrm{C}$ for 30 minutes. Four samples were prepared by mixing silica powder with 5 wt.\% excess of aluminum powder (99.9\%, Merck). The mixed powder was compacted to form a pelletshaped of $10 \mathrm{~mm}$ in diameter and $10 \mathrm{~mm}$ in height. The pellets were heat calcined at $700-900^{\circ} \mathrm{C}$ in the horizontal reactor under $\mathrm{CO}$ gas constant flow of 1.5 liters per minute for one hour. The samples were then leached using a mixture of 1.0 $\mathrm{M} \mathrm{HCl}$ and acetic acid (30 wt.\%) to remove aluminum oxide and other traceable metals and using a mixture of HF (10 wt.\%) and acetic acid (30 wt.\%) to dissolve the remaining unreacted silica and other form of compounds. Chemical leaching was performed for 6 hours at two different temperatures, i.e., $70^{\circ} \mathrm{C}$ and $90^{\circ} \mathrm{C}$.

Table 1. Silica extraction processes.

\begin{tabular}{lllll}
\hline \multirow{2}{*}{ Sample } & \multirow{2}{*}{ Chemical used } & \multicolumn{2}{l}{$\begin{array}{l}\text { Pressure cooker }(80 \\
\mathrm{kPa})\end{array}$} & \multicolumn{2}{l}{ Heat treatment } \\
\cline { 4 - 5 } & & none & - & - \\
& & $\left({ }^{\circ} \mathrm{C}\right)$ & $\dagger(\mathrm{min})$. \\
2 & none & none & 500 & 60 \\
3 & none & roasted & 500 & 60 \\
4 & none & roasted & 500 & 60 \\
5 & $\mathrm{CH}_{3} \mathrm{COOH}$ & roasted & 500 & 60 \\
6 & $\mathrm{CH}_{3} \mathrm{COOH}+\mathrm{EG}$ & roasted & 500 & 60 \\
7 & $\mathrm{CH}_{3} \mathrm{COOH}+\mathrm{H}_{2} \mathrm{O}_{2}$ & roasted & 500 & 60 \\
8 & $\mathrm{HCl}+\mathrm{H}_{2} \mathrm{O}_{2}$ & none & 500 & 60 \\
\hline
\end{tabular}


The recovered silicon was rinsed twice with distilled water. The microstructure and morphology of thermally decomposed rice husk, the reduction products, and the leached samples were examined by using an X-ray diffractometer (XRD, BRUKER D8 Advance) and Scanning Electron Microscopy (SEM, HITACHI SU3500), respectively. The chemical elements on the sample were identified by Energy Dispersion Spectroscopy (EDS, HITACHI SU3500) and chemical gravimetric analysis.

\section{RESULTS AND DISCUSSION}

\section{Thermal Decomposition of Rice Husk}

Chemical analysis of rice husk and extracted silica using atomic emission spectroscopy (AES) is shown in Table 2. Untreated rice husk contains 24.03 wt.\% silica and 64.48 wt.\% carbon, consisting of cellulose, hemicelluloses, and lignin (Kumar et al., 2010).

Firing rice husk at $500^{\circ} \mathrm{C}$ for one hour without chemical treatment produce white powder containing 93.37 wt.\% silica with remaining impurities intact in the husk matrix. The morphology of the as fired rice husk ash is shown in figure $1(\mathbf{a})$. It is clearly seen that the husk ash contains white silica in a fragile husk matrix, which is easily crushed to form silica powder, as shown in figure $\mathbf{1}(\mathbf{b})$. Firing the husk has crushed cellulose and lignin matrix revealing silica powder. Askaruly et al. (2020) fired rice husk for 4 hours at $500^{\circ} \mathrm{C}$ producing black ash, but no impurities were reported.

Firing the chemically untreated husk (sample 2) has completely eliminated carbon from the husk ash. Roasted the chemically untreated husk in a pressurized vessel containing water (sample 3) has reduced the concentration of all impurities. It suggests that pressurized cooking sufficiently destroyed the husk matrix and liberated the impurities from silica. Chemical analysis verifies that most alkaline oxides weakly attached to the husk matrix. Potassium oxide was found to fill in a particular location and undistributed in the husk matrix (Chen, Bie \& Bie, 2018). However, roasted the husk in the pressurized cooker was insufficiently enhanced total silica more than 99 wt.\%, even when acetic acid or acetic acidethylene glycol was used (sample 4-5). The addition of acetic acid has impacted, reduced $\mathrm{Fe}_{2} \mathrm{O}_{3}$ and $\mathrm{MgO}$, but increased $\mathrm{Al}_{2} \mathrm{O}_{3}, \mathrm{Na}_{2} \mathrm{O}$, and $\mathrm{K}_{2} \mathrm{O}$. Further effort to liberate the impurities from lignin and cellulose chains with ethylene glycol was unsuccessful. Acetic acid was only effective in esterifying oil from the husk during roasting.

When a mixture of acetic acid and hydrogen peroxide (sample 6) was used to roast the rice husk in the pressurized cooker, $\mathrm{Al}_{2} \mathrm{O}_{3}$ and $\mathrm{CaO}$ were slightly reduced, which yielded silica over 99 wt.\%. The use of weak acid apparently does not affect the $\mathrm{Fe}_{2} \mathrm{O}_{3}$ reduction, but it was effective in reducing $\mathrm{K}_{2} \mathrm{O}$. The $\mathrm{K}_{2} \mathrm{O}$ dissolved in water to form $\mathrm{KOH}$ during roasting, while $\mathrm{H}_{2} \mathrm{O}_{2}$ triggered acetic acid to liberate to form paracetic acid and water. Umeda \& Kondoh (2010) successfully removed $\mathrm{K}_{2} \mathrm{O}$ by soaking silica in a citric acid solution for 60 minutes at $80^{\circ} \mathrm{C}$, For comparison, silica extraction with alkali-fusion (sample 8) using a strong base and strong acid solutions yielded silica more than 99 wt.\%. Substitution acetic acid with chloric acid (sample 7) has an even pronounced effect on the elimination of $\mathrm{Al}_{2} \mathrm{O}_{3}$, and the reduction of $\mathrm{Fe}_{2} \mathrm{O}_{3}$ and $\mathrm{CaO}$. The reduction of these oxides was mainly due to excess heat available during combustion. The excess heat was triggered by the catalytic role of chloric acid in hydrogen peroxide to form $\mathrm{H}_{2}$ and $\mathrm{O}_{2}$ gases, which function as strong oxidants to enhance the heat produced during combustion. The excess heat generated destroyed the husk matrix of lignin and cellulose and liberated impurities during heat treatment. This process has yield the purity of silica of 99.81 wt.\%.

Table 2. Chemical analysis (wt.\%) of samples before and after chemical and heat treatment.

\begin{tabular}{lllllllll}
\hline Sample & $1^{*}$ & 2 & 3 & 4 & 5 & 6 & 7 & 8 \\
\hline $\mathrm{SiO}_{2}$ & 24.03 & 93.37 & 98.68 & 98.79 & 98.68 & 99.02 & 99.81 & 99.06 \\
$\mathrm{Al}_{2} \mathrm{O}_{3}$ & 0.54 & 0.53 & 0.06 & 0.17 & 0.14 & 0.01 & 0 & 0 \\
$\mathrm{Fe}_{2} \mathrm{O}_{3}$ & 1.10 & 1.10 & 0.34 & 0.05 & 0.40 & 0.40 & 0.05 & 0.37 \\
$\mathrm{CaO}$ & 0.84 & 0.84 & 0.38 & 0.32 & 0,54 & 0.38 & 0.02 & 0.03 \\
$\mathrm{MgO}$ & 0.22 & 0.21 & 0.22 & 0.05 & 0 & 0 & 0 & 0 \\
$\mathrm{Na} O$ & 0.40 & 0.40 & 0.1 & 0.22 & 0.01 & 0.01 & 0.02 & 0.04 \\
$\mathrm{~K}_{2} \mathrm{O}$ & 0.95 & 0.95 & 0.09 & 0.29 & 0.02 & 0.02 & 0.02 & 0.43 \\
$\mathrm{TiO}_{2}$ & 0.84 & 0.84 & 0 & 0 & 0.01 & 0.02 & 0.01 & 0.01 \\
$\mathrm{MnO} \mathrm{P}$ & 0.13 & 0.11 & 0.05 & 0.05 & 0.05 & 0.04 & 0.01 & 0.01 \\
$\mathrm{~S}$ & 1.33 & 1.25 & 0.08 & 0.06 & 0.08 & 0.05 & 0.02 & 0 \\
$\mathrm{C}$ & 0.40 & 0.40 & 0 & 0 & 0.07 & 0.05 & 0.02 & 0.05 \\
\hline
\end{tabular}

*Raw rice husk 

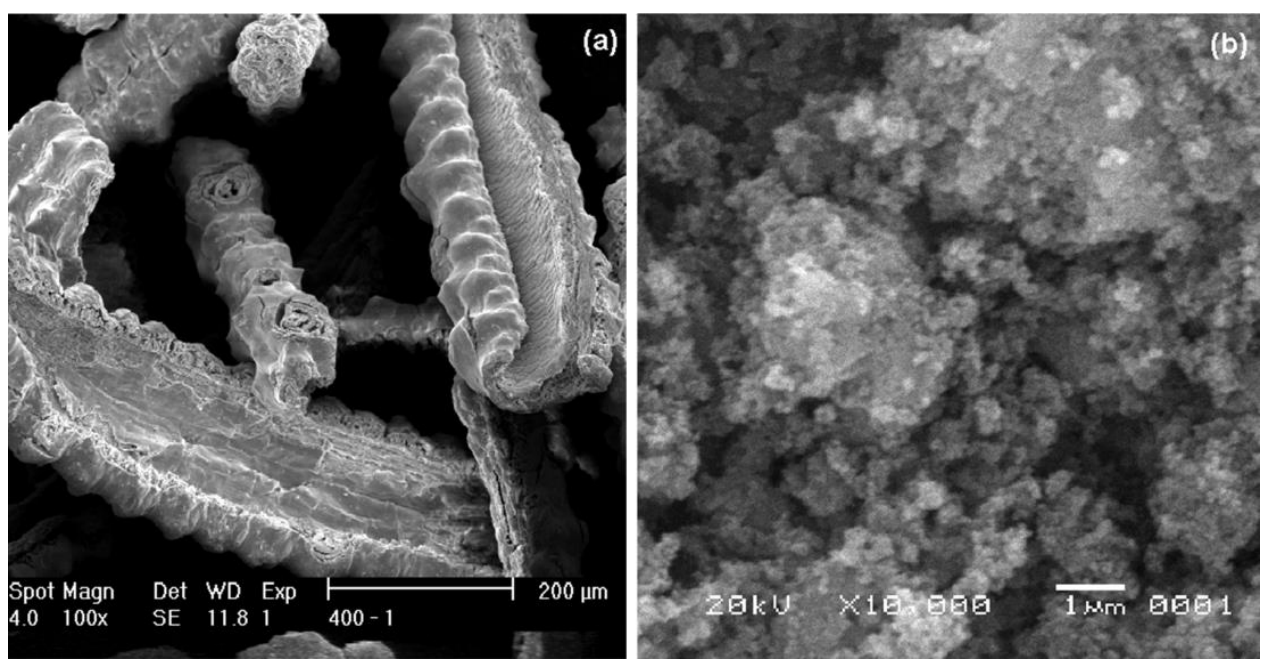

Figure 1. Morphology of (a) as fired rice husk ash, and (b) crushed rice husk ash.

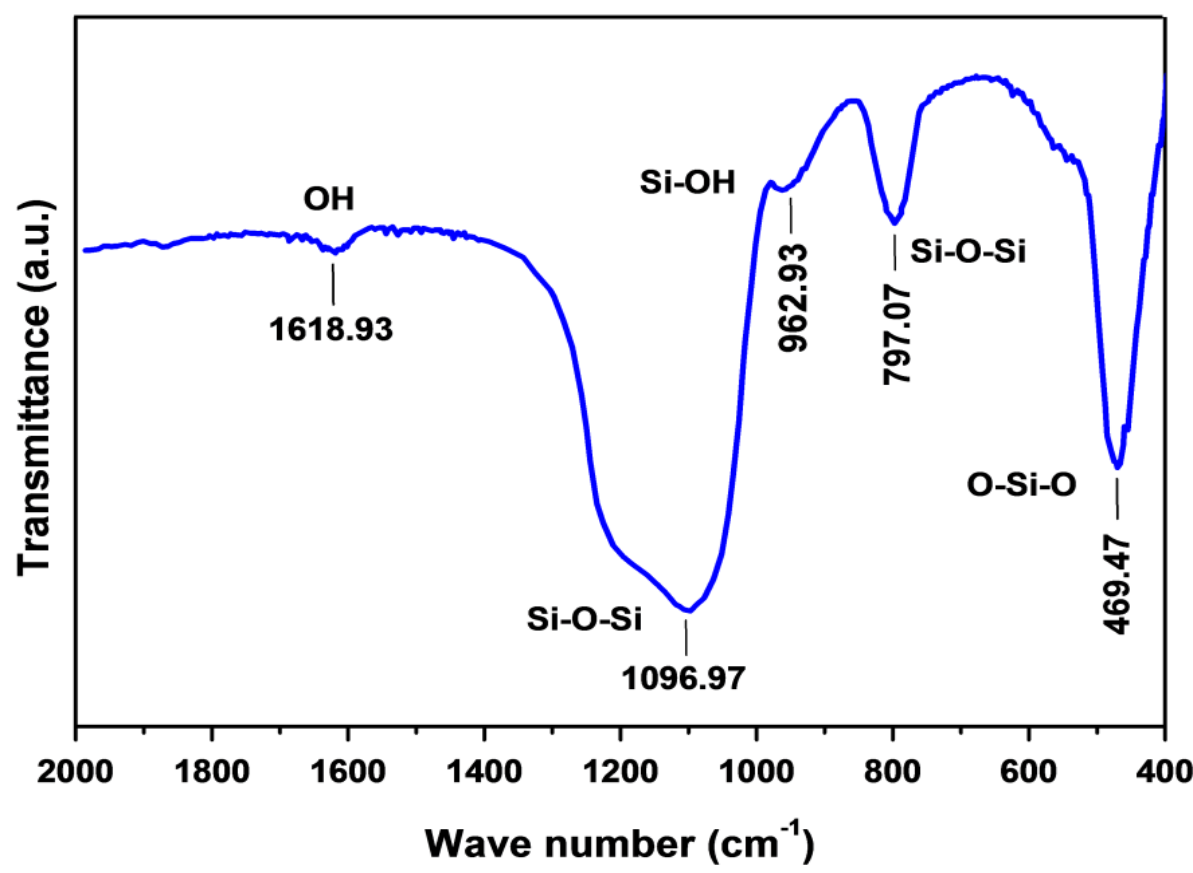

Figure 2. Fourier Transform Infrared (FTIR) of silica powder (sample 7).

Figure 2 shows the chemical bound of silica powder extracted by peroxide-chloric acid (sample7). The band at $1618.93 \mathrm{~cm}^{-1}$ represents the bending vibration of $\mathrm{OH}$. Spread band between 1300-1000 cm and peaked at $1096.97 \mathrm{~cm}^{-1}$ attributed asymmetric stretching vibration to siloxane bonding of $\mathrm{Si}-\mathrm{O}-\mathrm{Si}$ bridges. The absorption band at $962.93 \mathrm{~cm}^{-1}$ is symmetric stretching vibration of free silanol on the surface of $\mathrm{Si}-\mathrm{OH}$ solid amorphous. The absorption band at $797.07 \mathrm{~cm}^{-1}$ corresponds to the symmetric stretching vibration of $\mathrm{Si}-\mathrm{O}-\mathrm{Si}$ bonding. The absorption band at $469.47 \mathrm{~cm}^{-1}$ is associated with an asymmetric deformation vibration bonding of O-Si-O (Wardhani, Nurlela, \& Azizah, 2017).

\section{Aluminothermic Reduction of Silica}

The reduction process of silica by aluminum at temperature ranges $700-900^{\circ} \mathrm{C}$ take place according to the following equation: $3 \mathrm{SiO}_{2}+4 \mathrm{Al}$ $=2 \mathrm{Al}_{2} \mathrm{O}_{3}+3 \mathrm{Si}$. This theoretical figure of reaction may not result in $100 \%$ efficiency for producing a definite amount of silicon in the final product. The final product will be sensitively influenced by various factors, including temperature processes and an excess of aluminum contain in the sample.

Figure 3 shows the XRD pattern of the reduction products from the samples with $5 \mathrm{wt} \%$ excess of aluminum treated at different temperatures for one hour under $\mathrm{CO}$ flow. Three distinguish diffraction patterns of reduction products are depicted in 
Figure 4, i.e., the diffraction patterns at 700 and $750^{\circ} \mathrm{C}$, the patterns at 800 and $850^{\circ} \mathrm{C}$, and the pattern at $900^{\circ} \mathrm{C}$.

Under calcination temperature of $700^{\circ} \mathrm{C}$ and $750^{\circ} \mathrm{C}$, distinguishable peaks of silicon (solid-circle) and alumina (flipped open-triangle), and unreacted silica (open-circle) and aluminum (flipped solidtriangle) were observed, corresponding to the standard JCPDS No.75-0589, JCPDS No. 46-1212, JCPDS No.46-1045 and JCPDS No. 89-4037, respectively. Increase the temperature calcination from $700^{\circ} \mathrm{C}$ to $750^{\circ} \mathrm{C}$ enhanced the peak intensity of silicon and reduced the peak intensity of aluminum, indicating the reduction process occurs. However, at this calcination temperature ranges, aluminum were not able to completely convert silica to form silicon and alumina. Immediate result of silica-silica reduction is volatile oxygen, which could readily available to react with the aluminum to form alumina or reaction back with $\mathrm{Si}$ to form silica. The fact that the free energy for the formation of $\mathrm{SiO}_{2}$ and $\mathrm{Al}_{2} \mathrm{O}_{3}$ is quiet close. It suggests that there is a competing process between silica reformation and aluminum oxidation, in favor of formation of alumina. As the reduction temperature increases to $800^{\circ} \mathrm{C}$, there is a noticeable enhancement of the silicon peaks and diminishing the aluminum peaks. At the calcination temperature ranges of $800-850^{\circ} \mathrm{C}$, aluminum peaks disappeared, but silica peaks still present. It indicates that aluminum has entirely reacted with silica, as shown by raising the diffraction peak intensity of silicon and alumina. Further increase the calcination temperature up to $900^{\circ} \mathrm{C}$ additional peaks appeared which resemble the diffraction peak of mullite, $\mathrm{Al}_{6} \mathrm{Si}_{2} \mathrm{O}_{13}$ (solid diamond) according to the standard JCPDS No. 15-0776 and the silica peaks disappear. Two possible competing reactions could occur at $900^{\circ} \mathrm{C}$, i.e., the formation of mullite from alumina and silica, and reduction of mullite to form silicon and alumina. Possible reaction for the formation of mullite is $2 \mathrm{SiO}_{2}+3 \mathrm{Al}_{2} \mathrm{O}_{3}=\mathrm{Al}_{6} \mathrm{Si}_{2} \mathrm{O}_{13}$, and the reduction of mullite by aluminum is $3 \mathrm{Al}_{6} \mathrm{Si}_{2} \mathrm{O}_{13}+8 \mathrm{Al}=6 \mathrm{Si}+$ $13 \mathrm{Al}_{2} \mathrm{O}_{3}$ (Sarkar \& Mallick, 2018; Suriyanarayanan, Nithin, \& Bernardo, 2009).

Figure 4 shows silicon yield from the reduction product calcined at different temperatures for one hour under $\mathrm{CO}$ flow. As the calcination temperature increases from $700^{\circ} \mathrm{C}$ to $800^{\circ} \mathrm{C}$, the silicon yield increases to a maximum of $78.6 \%$ and incrementally decreases as the calcination temperature is increased to $900^{\circ} \mathrm{C}$. The decrease of silicon yield may be due to the formation of the mullite phase $\left(3 \mathrm{Al}_{2} \mathrm{O}_{3} .2 \mathrm{SiO}_{2}\right)$, starting at around $850^{\circ} \mathrm{C}$, which inhibits the formation of silicon.

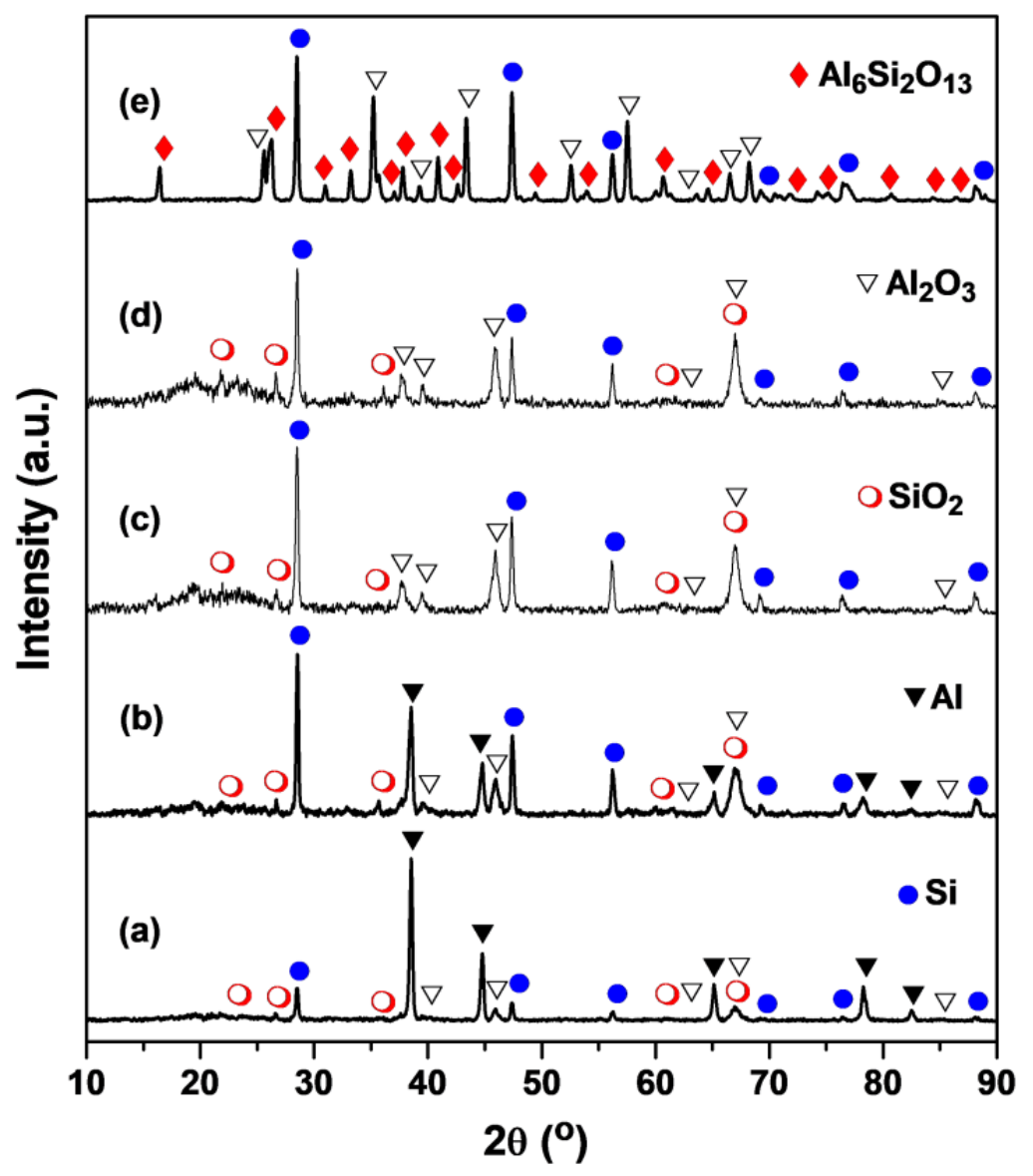

Figure 3. XRD pattern of silica reduced 5 wt. $\%$ excess of aluminum at $(\mathbf{a}) 700^{\circ} \mathrm{C}$, (b) $750^{\circ} \mathrm{C}$, (c) $800^{\circ} \mathrm{C}$, (d) $850^{\circ} \mathrm{C}$, and (e) $900^{\circ} \mathrm{C}$. 


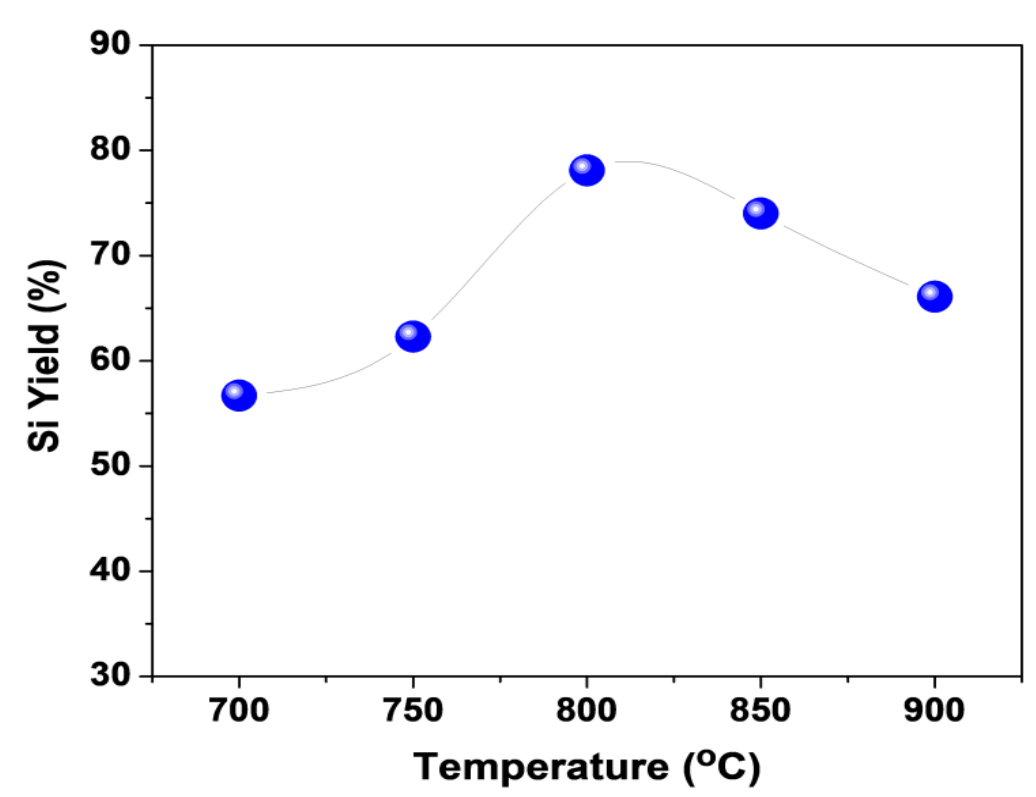

Figure 4. Silicon yield from reduction product.

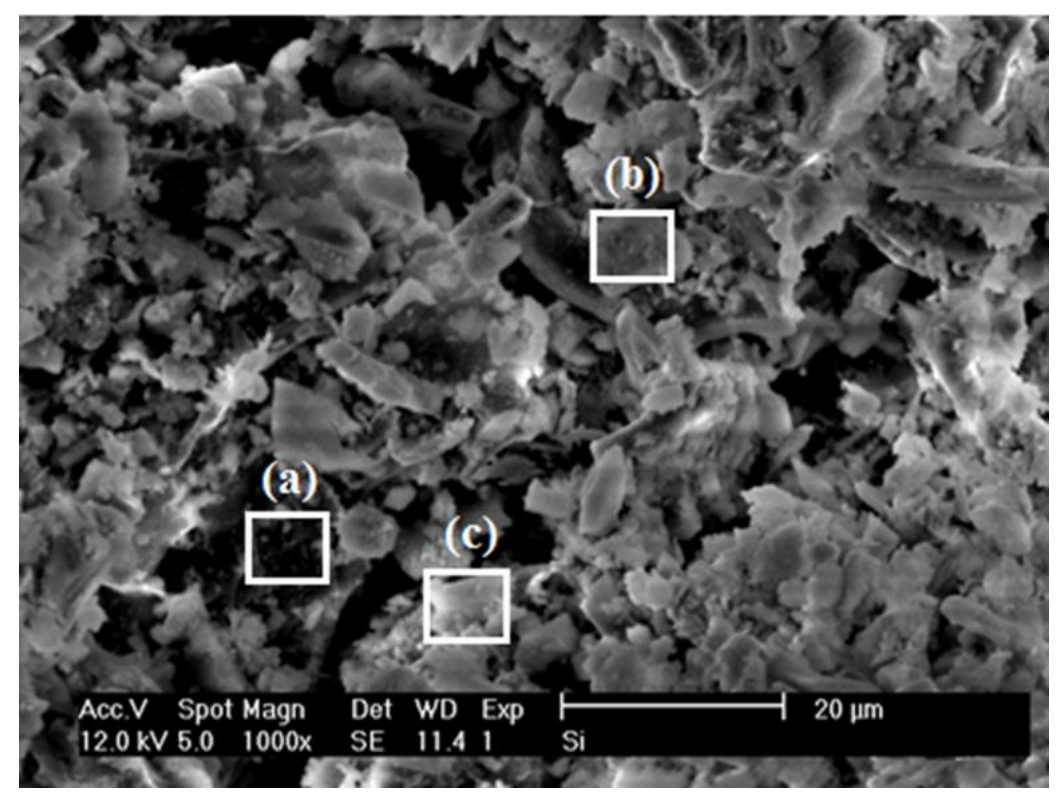

Figure 5. SEM picture of the reduction product from the sample with $5 \mathrm{wt} . \% \mathrm{Al}$ excess treated at $800{ }^{\circ} \mathrm{C}$ for $1 \mathrm{~h}$.

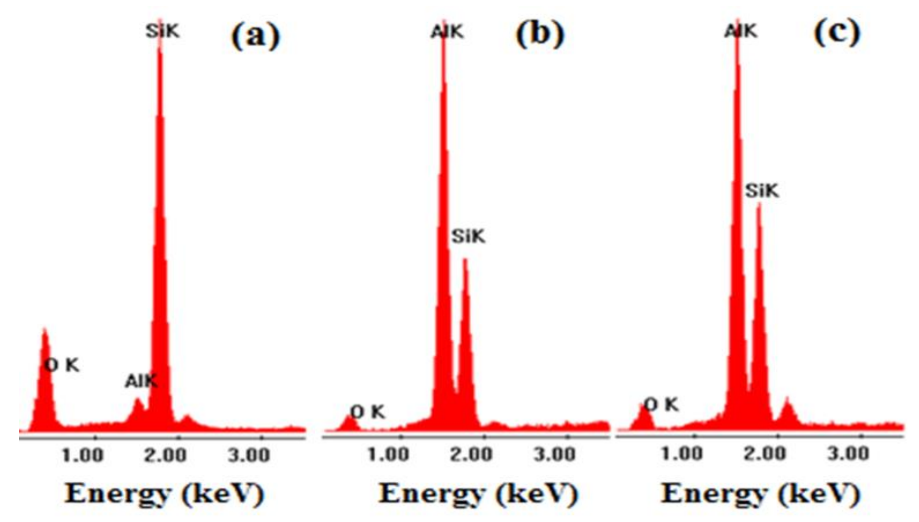

Figure 6. EDS spectrum of the sample at position (a), (b), and (c) from SEM picture in Figure 5. 


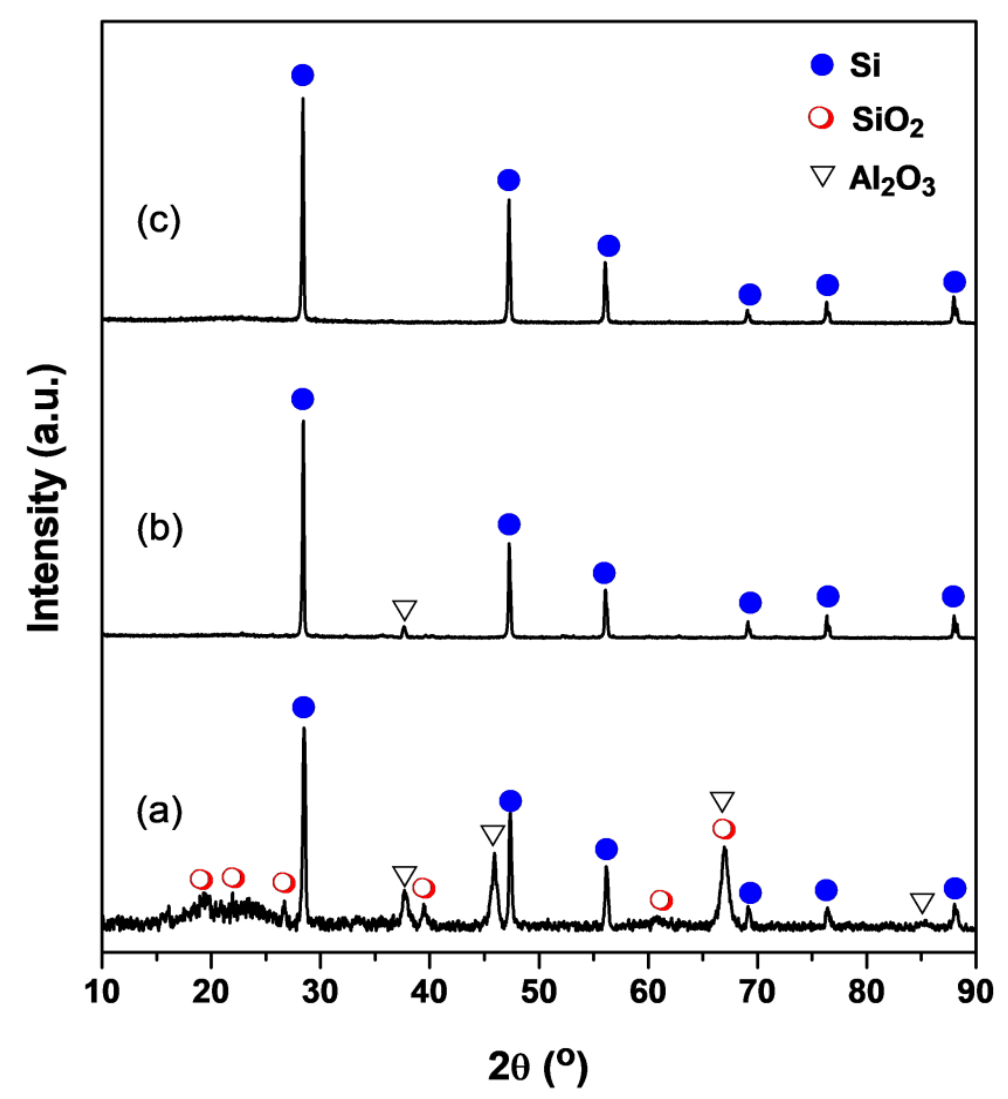

Figure 7. XRD pattern of silica reduction products after leaching for $6 \mathrm{~h}$ at a temperature of (a) $25^{\circ} \mathrm{C}$, (b) $70^{\circ} \mathrm{C}$, and (c) $90^{\circ} \mathrm{C}$.

Figure 5 presents the microstructure image of the reduction product prepared at $800^{\circ} \mathrm{C}$. There is clearly that the surface morphology of the sample contains irregularly shaped of the inhomogeneous mix of silicon, silica, aluminum, and alumina. Three different spots on the sample surface with different morphology were further observed by EDS, as shown in Figure 6. All spots contain silicon and aluminum with different concentrations, i.e., the dark spot (a) resembles major silicon while the dark-gray and lightgray spots (b and $\mathbf{c}$ ) contain major aluminum and minor silicon.

Figure 7 shows the XRD pattern of the sample calcined at $800^{\circ} \mathrm{C}$ and leached using strong hydrochloric and hydrofluoric acids at three different leaching temperatures. The sample leached at room temperature for 6 hours, shown in Figure $7(\mathbf{a})$, has little effect in reducing silica and alumina in the sample. When the leaching temperature is set at $70^{\circ} \mathrm{C}$ for 6 hours, silica was entirely removed from the sample, but there is a small quantity of alumina detectable in the diffraction pattern, as shown in Figure $7(b)$. Leaching the sample at $90^{\circ} \mathrm{C}$ for 6 hours silica and alumina were completely removed from the sample, as shown in Figure $7(c)$. XRF measurement of the sample leached at $90^{\circ} \mathrm{C}$ for 6 hours shows that silicon polycrystalline has a purity of $99.91 \%$.

\section{CONCLUSIONS}

Polycrystalline silicon could be prepared with cheaper cost using the combination of thermal decomposition of rice husk and aluminothermic reduction at medium temperatures. The optimum conditions of thermal decomposition of rice husk were determined to prepare high purity silica powder with narrow particle size distribution. Roasted the rice husk in pressurized cooker containing a mixture of chloric acid and hydrogen peroxide, and direct burnt of dried roasted husk at $500^{\circ} \mathrm{C}$ for one hour produced high purity of 99.81 wt.\% silica powder. Aluminothermic reduction of silica at $800^{\circ} \mathrm{C}$ using 5 wt.\% excess of aluminum powder yield $78.6 \%$ silicon, which can be leached effectively in strong chloric acid and fluoric acid to produce polycrystalline silicon with $99.91 \%$ purity.

\section{ACKNOWLEDGMENTS}

This work is supported by the Institut Teknologi Bandung through Research Group Grant.

\section{REFERENCES}

Ali, H. H. M., El-Sadek, M. H., Morsi, M. B., El-Barawy, K. A., \& Abou-Shahba, R. M. (2018). Production of metallurgical-grade silicon from Egyptian quartz. Journal of the Southern African Institute of Mining and Metallurgy, 118(2), 143-148. 
Askaruly, K., Azat, S., Sartova, Z., Yeleuov, M., Kerimkulova, \& A., Bekseitova, K. (2020). Obtaining and characterization of amorphous silicon from rice husk. Journal of Chemical Technology and Metallurgy, 55(1), 88-97.

Azat, S., Sartova, Z., Bekseitova, K., \& Askaruly, K. (2019). Extraction of high-purity silica from rice husk via hydrochloric acid leaching treatment. Turkish Journal of Chemistry, 43, 1258-1269.

Barati, M., Sarder, S., Mclean, A., \& Roy, R. (2011). Recovery of silicon from silica fume. Journal of Non-Crystalline Solids, 357(1), 18-23.

Chen, P., Bie, H. \& Bie, R. (2018). Leaching characteristics and kinetics of the metal impurities present in rice husk during pretreatment for the production of nanosilica particles. Korean J. Chem. Eng. 35, 19111918.

FAO. (2017). 117---2017-Rice Market Monitor-July. $X X(2)$.

Fijalkowski, M., Adach, K., Petráň, A., \& Kroisová, D. (2016). Rice Husks - structure, composition and possibility of use them at surface treatment. Materials Science Forum, 844, 153-156.

Haouli, S., Boudebane, S., Slipper, I.J., Lemboub, S., Gebara, \& P., Mezrag, S. (2018). Combustion synthesis of silicon by magnesiothermic reduction. Phosphorus, Surfur, and Silicon, 193(5), 280-287.

Kumar, P.S., Ramakrishnan, K., Kirupha, S.D., \& Sivanesan, S. (2010). Thermodynamic and kinetic studies of cadmium adsorption from aqueous solution onto rice husk. Brazilian Journal of Chemical Engineering, 27(2), 347355.

Larbi, K.K., Barati, M., \& McLean, A. (2013). Reduction behaviour of rice husk ash for preparation of high purity silicon. Canadian Metallurgical Quarterly, 50(4), 341-349.

Loutzenhiser, P. G., Tuerk, O., \& Steinfeld, A. (2010). Production of $\mathrm{Si}$ by vacuum carbothermal reduction of $\mathrm{SiO}_{2}$ using concentrated solar energy. JOM, 62(9), 49-54.

Lynch, D. (2009). Winning the global race for solar silicon. JOM, 61(11), 41-48.

Okutani, T. (2009). Utilization of silica in rice hulls as raw materials for silicon semiconductors. Journal of Metals, Materials and Minerals, 19(2), 51-59.

Sarkar, R., \& Mallick, M. (2018). Formation and densification of mullite through solidoxidereaction technique using commercialgrade raw materials. Bulletin Materials Science, 41,31 .

Selvakumar, K. V, Umesh, A., Ezhilkumar, P., Gayatri, S., Vinith, P., \& Vignesh, V. (2014). Extraction of silica from burnt paddy husk. International Journal of ChemTech Research, 6(9), 44554459.

Suriyanarayanan, N., Nithin, K. V. K., \& Bernardo, E. (2009). Mullite glass ceramics production from coal ash and alumina by high temperature plasma. Journal of Non-Oxide Glasses, 1(4), 247-260.

Swatsitang, E., \& Krochai, M. (2009). Preparation and characterization of silicon from rice hulls. Journal of Metals, Materials and Minerals, 19(2), 91-94.

Umeda, J., \& Kondoh, K. (2010). High-purification of amorphous silica originated from rice husks by combination of polysaccharide hydrolysis and metallic impurities removal. Industrial Crops and Products, 32, 539-544.

Ugheoke, I. B., \& Mamat, O. (2012). A critical assessment and new research directions of rice husk silica processing methods and properties. Maejo International Journal of Science and Technology, 6(3), 430.

Yuvakkumar, R., Elango, V., Rajendran, V., \& Kannan, N. (2014). High-purity nano silica powder from rice husk using a simple chemical method. Journal of Experimental Nanoscience, 9(3), 272-281.

Wardhani, G. A. P. K, Nurlela, \& Azizah, M. (2017). Silica Content and Structure from Corncob Ash with Various Acid Treatment $(\mathrm{HCl}, \mathrm{HBr}$, and Citric Acid). Molekul, 12(2), 174-181.

Won, C. W., Nersisyan, H. H., \& Won, H. I. (2011). Solar-grade silicon powder prepared by combining combustion synthesis with hydrometallurgy. Solar Energy Materials \& Solar Cells, 95, 745-75. 